\title{
Mobilyada Kullanılan Tasarım Öğelerinin Psikolojik Etkileri
}

\author{
Hüseyin YEŞIL ${ }^{1}$ \\ ${ }^{1}$ Dr. Öğr. Üyesi, Kütahya Dumlupınar Üniversitesi, Simav Meslek Yüksek Okulu, Tasarım Bölümü, \\ Simav, Kütahya/Türkiye, huseyin.yesil@dpu.edu.tr \\ Mustafa ORDU ${ }^{2}$ \\ ${ }^{2}$ Öğr. Gör., Kütahya Dumlupınar Üniversitesi, Simav Meslek Yüksek Okulu, Tasarım Bölümü, Simav, \\ Kütahya/Türkiye, mustafa.ordu@dpu.edu.tr \\ Sait Dündar SOFUOĞLU ${ }^{3}$ \\ ${ }^{3}$ Doç. Dr., Kütahya Dumlupınar Üniversitesi, Simav Teknoloji Fakültesi, Ağaç İşleri Endüstri \\ Mühendisliği Bölümü, Simav, Kütahya, Türkiye, sdundar.sofuoglu@ dpu.edu.tr
}

\begin{tabular}{|c|c|}
\hline Makale Bilgileri & ÖZ \\
\hline $\begin{array}{l}\text { Makale Geçmişi } \\
\text { Geliş: } 12.10 .2021 \\
\text { Kabul: } 06.12 .2021 \\
\text { Yayın: } 21.12 .2021 \\
\text { Anahtar } \\
\text { Kelimeler: } \\
\text { Mobilya, } \\
\text { Tasarım, } \\
\text { Psikoloji, }\end{array}$ & $\begin{array}{l}\text { Mobilya tasarımı, mimari tasarım ve endüstrinin birçok dallarındaki tasarımlara benzerdir. Bu } \\
\text { dallarda kullanılan tasarım yöntemleri mobilya tasarlamada da kullanılabilmektedir. Tasarım } \\
\text { sürecinde elde edilecek sonuçların çeşitliliği tasarımcıya bağlıdır. Temel tasarım elemanlarının etkin } \\
\text { bir biçimde kullanılması tasarım süreci açısından vazgeçilmez bir gerekliliktir. Bu nedenle ürün } \\
\text { tasarımcıları tasarım süreçlerine yenilik getirerek; tek başına düzensiz görünen parçaları, tasarım } \\
\text { elemanlarını oluşturan nokta, çizgi, yön ve doğrultu, yüzey, alan, orantı, ölçü ve boyut, biçim ve } \\
\text { form, renk, doku'dan faydalanarak sonuçlandırmaktadırlar. Tasarım elemanlarının etkin kullanımı } \\
\text { ve insan psikolojisi üzerindeki etkisinin bilinmesi tasarlanan mobilyanın istenen tasarım hedefine } \\
\text { ulaşmasını sağlayacaktır. Çalışmada tasarım elemanları hakkında öz bilgiler verildikten sonra, insan } \\
\text { psikolojisi üzerindeki etkisi açılanmıştır. Mobilya tasarımı yapan kişi ve kurumlar insan } \\
\text { psikolojisinin önemli olduğu, ürünü beğenme ve satın alma arzusunun oluşturulmasının gerektiği } \\
\text { ticari bakış açısıyla bu faktörleri optimum kullanabileceklerdir. Özellikle ortak kullanım alanlarında } \\
\text { (okul, hastahane, otel, konferans salonu, lobi vb.) bu faktörleri göz önüne alarak tasarımların } \\
\text { gerçekleştirildiği mobilyalar kullanıldığında istenilen psikolojik etki (huzur, hareket, güven vb) } \\
\text { oluşturulabilecektir. Sonuç olarak her tasarım parametresinin uygun bir şekilde ve bilinçli olarak }\end{array}$ \\
\hline
\end{tabular}

kullanımı ile tasarlanan ürünün kullanıcılar üzerinde etkisi istenilen şekilde olabilecektir.

\begin{tabular}{|c|c|}
\hline Article Info & ABSTRACT \\
\hline $\begin{array}{l}\text { Article History } \\
\text { Received: } 12.10 .2021 \\
\text { Accepted: } 06.12 .2021 \\
\text { Published: } 21.12 .2021 \\
\text { Keywords: } \\
\text { Furniture, } \\
\text { Design, } \\
\text { Psychology, }\end{array}$ & $\begin{array}{l}\text { Furniture design is similar to architectural design and designs in many branches of industry. The } \\
\text { design methods used in these branches can also be used in furniture design. The variety of results to } \\
\text { be obtained in the design process depends on the designer. The effective use of basic design elements } \\
\text { is an indispensable requirement for the design process. For this reason, product designers bring } \\
\text { innovation to the design processes; They conclude the irregular pieces by making use of the point, } \\
\text { line, direction, surface, area, proportion, size and dimension, form and form, color and texture that } \\
\text { constitute the design elements. Knowing the effective use of design elements and their effects on } \\
\text { human psychology will enable the designed furniture to reach the desired design goal. After giving } \\
\text { basic information about design elements, the study explains its effect on human psychology. } \\
\text { Furniture designing people and institutions will be able to use these factors optimally from a } \\
\text { commercial point of view. Human psychology is important, and the desire to like and buy the } \\
\text { product should be created. Especially in common areas (school, hospital, hotel, conference hall, } \\
\text { lobby, etc.), the desired psychological effect (peace, movement, confidence, etc.) can be created } \\
\text { when the furniture in which the designs are made is used, considering these factors. As a result, with } \\
\text { the appropriate and conscious use of each design parameter, the effect of the designed product on } \\
\text { the users can be as desired. }\end{array}$ \\
\hline
\end{tabular}

Attf/Citation: Yeşil H. Ordu M. Sofuoğlu S. D. (2021), Mobilyada Kullanılan Tasarım Öğelerinin Psikolojik Etkileri, Konya Sanat Dergisi, 4, 36-51. 


\section{GíRiş}

Türkçede "Tasarım" kelimesi Latince "designare" (göstermek) kökünden türemiştir. İngilizceye geçen "desing" terimi ile yaygın olarak kullanılmaktadır (Kurtoğlu ve Evci, 1988).

Tasarım sürecinde elde edilecek sonuçların çeşitliliği tasarımcıya bağlıdır. Tasarlama süreci her tasarımcıya göre farklılık gösterse de, her tasarım bir fikirle başlamaktadır. Bu noktada zihinde oluşan fikirlerin sonuç ürüne dönüşmesi izlenecek yöntem açısından oldukça önemlidir. Farklı fikirlerle aynı yöntem izlenerek farklı sonuçlara ulaşabileceği gibi aynı fikirle de farklı yöntemler izlendiğinde farklı sonuçlara ulaşlabilir. Her tasarımcının kendine özgü bir tasarlama sistemi olmaktadır. Tasarlama eyleminin başlangıcındaki fikrin somutlaştırılmasında tasarımcının kendine bir başlangıç noktası belirlemesi uygun olmaktadır.

Günümüzde tasarım süreci tasarımcının gerçekleştirdiği bir eylem, tasarımcı tarafından yönetilen bir süreç olarak gözükse de tasarımda kullanılan verilerin temel sağlayıcısının kullanıcı olarak ele alınması ve kullanıcının gereksinim ve beklentilerinin karşılanması ile kullanıcının tasarım sürecindeki önemi vurgulanmaktadır (Tütüncü, 2011).

\section{GENEL TASARIM ÖĞELERİ VE PSÍKOLOJIKK ETKİLERİ}

Temel tasarım elemanlarının uygun olarak kullanılması tasarım sürecinde olması gereken bir zorunluluktur. Tasarımcılar tasarım süreçlerinde, düzensiz parçaları nokta, çizgi, düzlem-hacim, biçimform, aralık, doku, yön ve renk gibi tasarım elemanlarını oluşturan öğeleri kullanmaktadırlar (KumasSenol ve Elmas, 2021).

\subsection{Nokta ve Çizgi}

Nokta; düzensizliğin içindeki ilk düzen elemanıdır (Kesen, 2005). Bir çizginin iki ucunu, iki çizginin kesişimini, bir düzlem ya da hacmin köşesindeki iki çizginin buluşmasını, bir alanın merkezini belirlemeye etkisi olan elemandır (Ching, 2002).

Nokta kavramsal olarak biçimsiz ve şekilsiz olsa da görüş alanına girdiğinde varlığı hissedilmeye başlar. Çevresinin merkezinde, nokta hareketsiz ve dinlenme halindedir ve çevresindeki öğeleri düzenleyerek alanı egemenliğine altına alabilmektedir (Andarood, 2014).

Çizgi; kalın veya kırılgan, gerilmiş veya gevşek, gösterişli veya çentikli olabilen çizgilerin görsel özellikleri, uzunluk-genişlik oranları, dış hat çizgilerine ve süreklilik derecelerini algılamamıza bağlıdır (Andarood, 2014).

Aslan vd. (2015)'in Dinçer (2011)'den aktarımına göre "Eğri çizgiler zarafet/kibarlık, gençlik, neşe ve incelikli hareketin göstergesidir. Geniş eğri çizgiler ilham vericidir. Yatay eğriler kibarlık ve rahat hareketi belirtir, geniş aşağı doğru eğriler hoş bir sertlik ve toprağa bağlı kalma duygusu verir, küçük eğriler ise neşeyi ve oyunu belirtir” (Aslan vd., 2015).

Çizgi, iki nokta arasındaki hat olarak ifade edilebilir (Buyurgan, 2012). Çizgi Sonsuz noktalardan oluşur ve tasarımda önemlidir. Çizgi hayal gücümüzün en kolay ifade edilmesini sağlar (Gökaydın, 2010). Hareket hâlindeki bir noktanın belirli bir yöndeki eğiminden çizgi meydana gelmektedir (Yılmaz, 2010). Çizgi hareketli ucun yüzey üzerinde bıraktığı aralıksız izdir (Kesen, 2009). Değişik çizgilerin yarattığı anlamlar Şekil 1'de, düşey çizgilerin hakim olduğu bir mobilya örneği Şekil 2'de verilmektedir. 


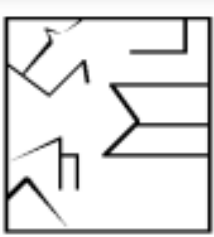

Katı malzemedeki kınk çizgiler kararsızlık ve ôlümsulzlôk ifade eder

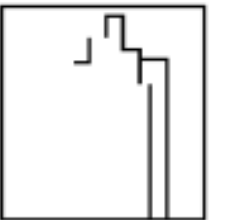

Yükselen çizgiler devamlilik, azamet ve kudret ifade ederler.

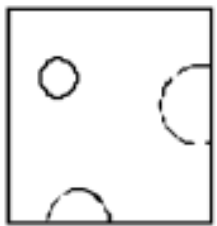

Yuvarlak çizgiler, esneklik, çoğalma

duygusu, genişlik ifade ederler.

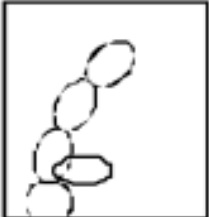

Oval çizgiler; iyilik, devamllik, yaraticilik ifade ederler.

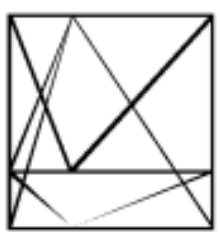

Merkezi yanda biçimsel olmayan çizgiler esneklik, gelişme hareketlilik ifade ederler

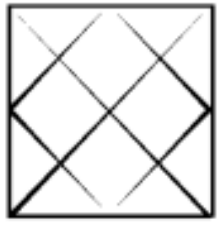

Merkezi ortada biçimsel olan çizgiler beraberlik, denge, aşin uygunluk ve simetriyi ifade ederler.

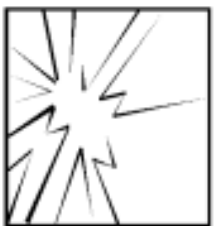

Belli bir merkezde toplanan kink çizgiler; heyecan, patlama

duygusu ifade ederler

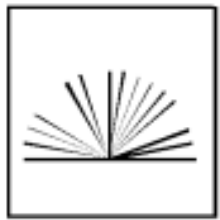

Bir noktadan dağilan dũz çizgiler; umut etme, yükselme ifade ederler

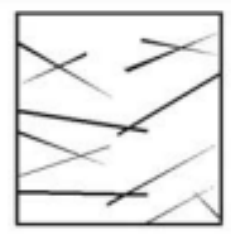

Meyilli olarak birbirini kesen çizgiler; çatışma, şiddet duygusu ifade ederler.

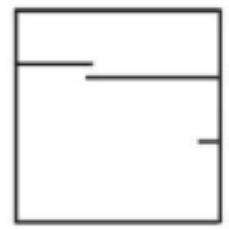

Yatay çizgiler sủkânet ve huzur ifade ederler

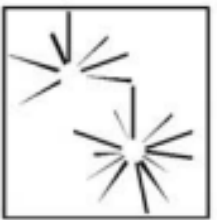

Bir noktadan çıkan çizgiler; radyasyon, titreşim, kuwvet ifade ederler

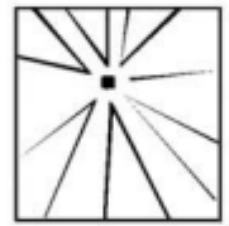

Bir noktaya doğru giden çizgiler; dikkat çekme, şoke etme, etkilemeyi ifade eder

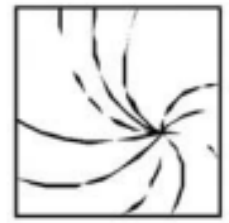

Bir merkezden qikan eğri çizgiler; ritim, beraberlik, çekicilik ifade ederler.

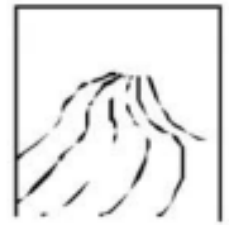

Aşağıya doğgru akan eğri çizgiler ritim, beraberlik, çekicilik ifade ederler

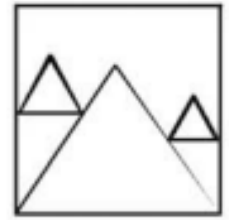

Birbirini destekleyen

kırk çizgiler; emniyet, güven ve güçlülūk ifade ederler

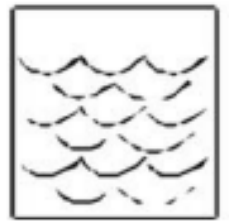

Olcçulà eğri çizgiler; kiși ũzerinde yumuşak etki burakırlar ve neşe duygusu verirler.

Şekil 1. Değişik çizgilerin yarattı̆̆ anlamlar (Özkartal, 2009) 
Çizgi bir ifade ve iletişimde geçmişten günümüze her zaman yerini korumuştur (Şengir, 2016).

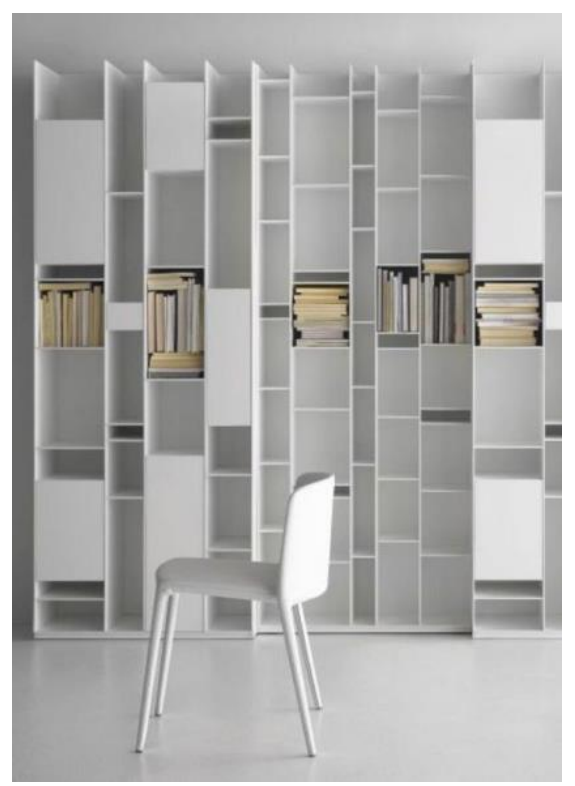

Şekil 2. Düşey çizgilerin hakim olduğu bir mobilya örn eği (URL-1)

\subsection{Yön ve doğrultu}

Çizgiler yönleri açısından değerlendirildiğinde genellikle yatay yönler edilgen durgunluğu ve sadeliği, yukarıdan aşağıya doğru insanda kararlılık ve dengeyi aşağıdan yukarı enerjiyi, zindeliği ve dinanizmi, düşeye yakın eğik yönlendirmeler etken (aktif) şiddeti, coşkuyu simgeler ve canlı, dinamik olarak etki yaparlar. Yön tasarımı meydana getirmede en önemli öğelerden birisidir. Aynı yöndeki konumlar monotonluk ve sıkıcılık hissi yaratır. Gerektikçe farklı yönler kullanmak suretiyle bir tasarımın bünyesine hareket, canlılık ve ilgi çekicilik vb psikolojik etkiler kazandırılabilmektedirler. Aynı çizgileri insanlara yatay olarak vaya düşey olarak sunulduğunda farklı etkiler bırakmaktadır. Yatay bir doğru hareketsiz veya statiktik etki bırakırken, düşey konumda doğru ise dinamik etki bırakmaktadır. Yatay konuma yaklaştıkça dinanizmi kaybolur (URL-2). Çeşitli yönde formlar verilerek hazırlanmış ve ana hatlarıyla tasarlanmış askılık örnenleri görülmektedir (Şekil 3) (Sofuoglu, 2013).
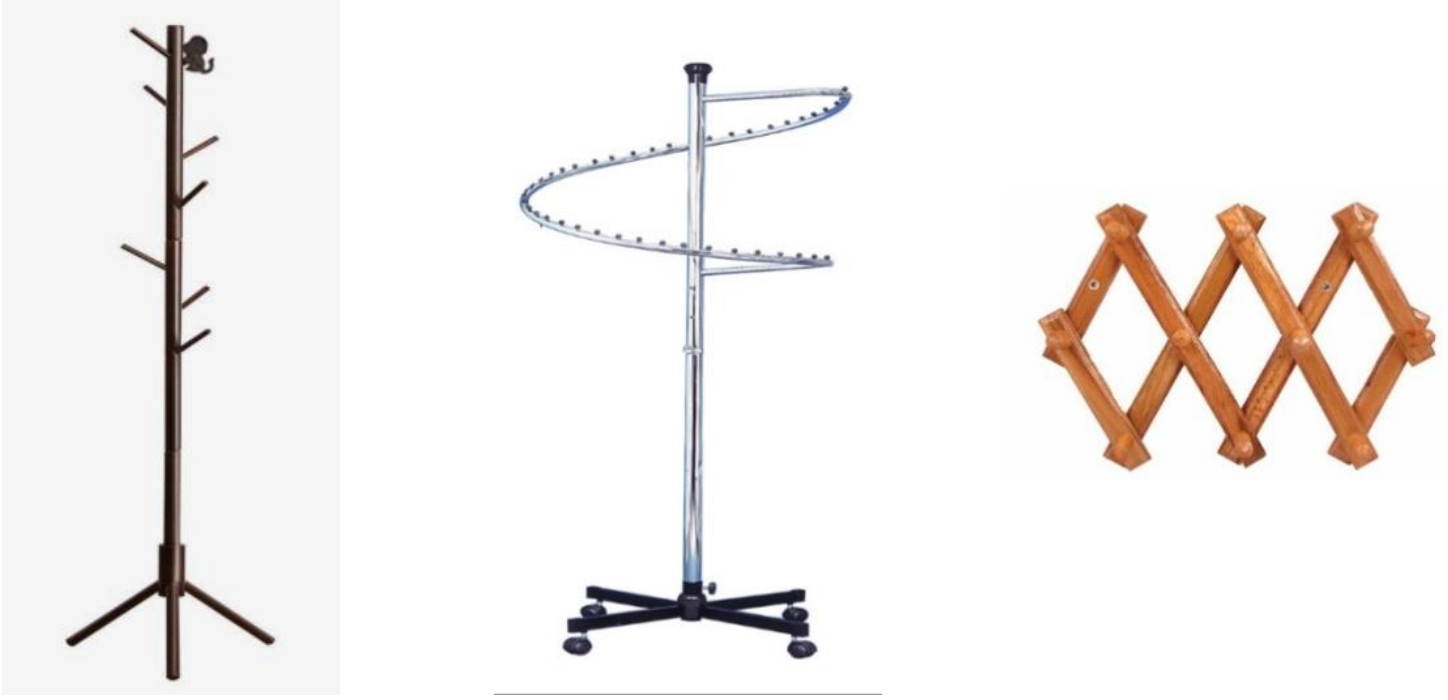

Şekil 3. Çizgi çalışmalarına uygun askılık modelleri (URL-3, URL-4, URL-5) 


\subsection{Yüzey}

Yüzeyler, boyutlarının konumlarına göre farklı psikolojik etkiler ifade ettiği gibi, başka yüzeyler ile iç içe bulundukları zaman da birtakım farklı etkiler ifade etmektedirler.

Yüksek bir düşey dikdörtgen yüzey, küçük yatay dikdörtgen yüzeylere bölünürse, kendi psikolojik etkisini kaybederek, yatay dikdörtgen yüzey etkisi ortaya çıkarmaktadır. Bu durum yatay bir dikdörtgen yüzeyin düşey dikdörtgen yüzeylere bölünmesi halinde de görülmektedir (Şekil 4). Yüzeylerin bu özelliği tasarımcı tarafından mobilyanın aşırı ölçüdeki, fonksiyonel boyutlarına ters yönde psikolojik etki yapacak estetik görünüm ve psikolojik etki kazandırmada kullanılabilmektedir (Sofuoglu, 2013).
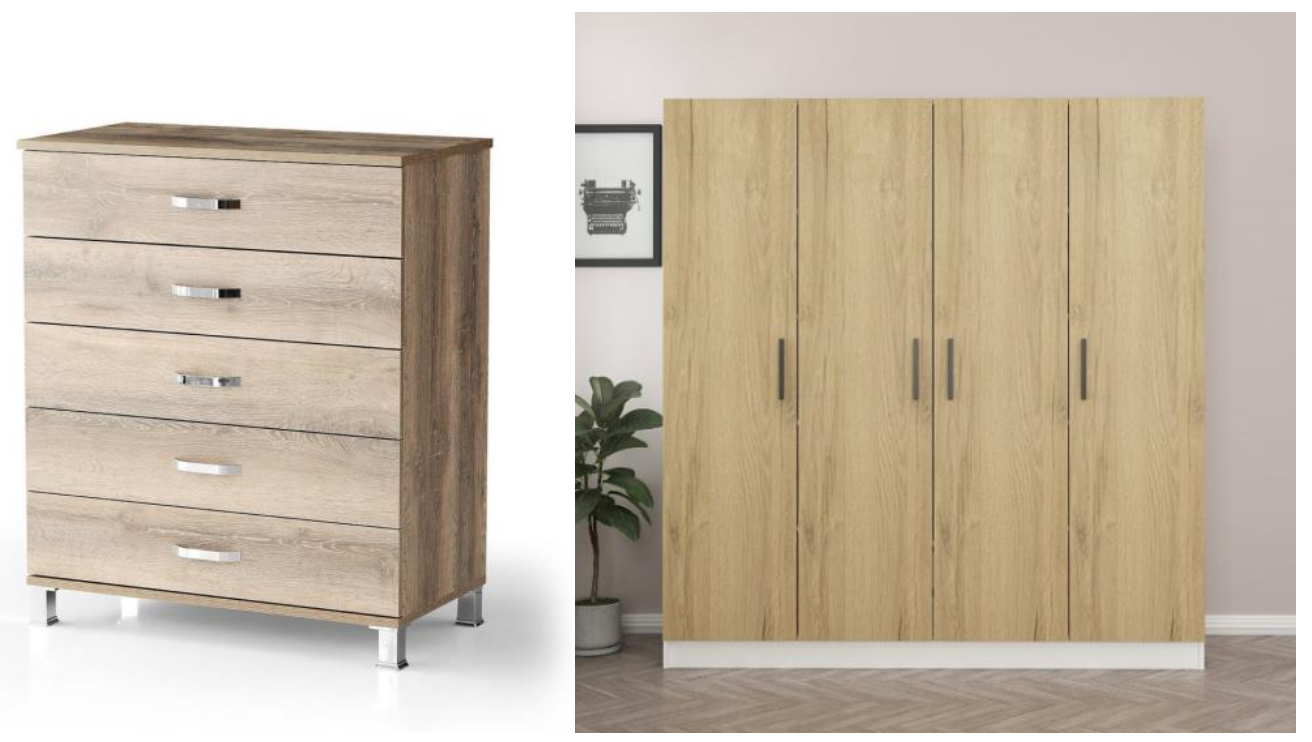

Şekil 4. Yüzeyi farklı dikdörtgenlere bölünmüss mobilyalar (URL-6, URL-7)

\subsection{Alan}

Alan olgusu görsel algılamamızı kapalı ve açık olmak üzere iki şekilde etkilemektedir. Mobilyada dolu alanlar kapak, çekmece gibi elemanlar ile boş alanlar ise raf aralıkları ve mobilya gövdesi içindeki boşluklar ile sağlanmaktadır. Ayrıca yatak altlarındaki boşluklar geçmişte gereksiz eşya deposu olarak kullanılmış olsalar da günümüzde alanların dar olmasından dolayı, daha verimli kullanılması için son derece kullanışlı hale getirilmişlerdir. Baza, çekyat vb. ürünler günümüzde yüksek oranda kullanılmaktadır (Sofuoglu, 2013). Dolu ve boş alanlar Şekil 5'de görülmektedir. 

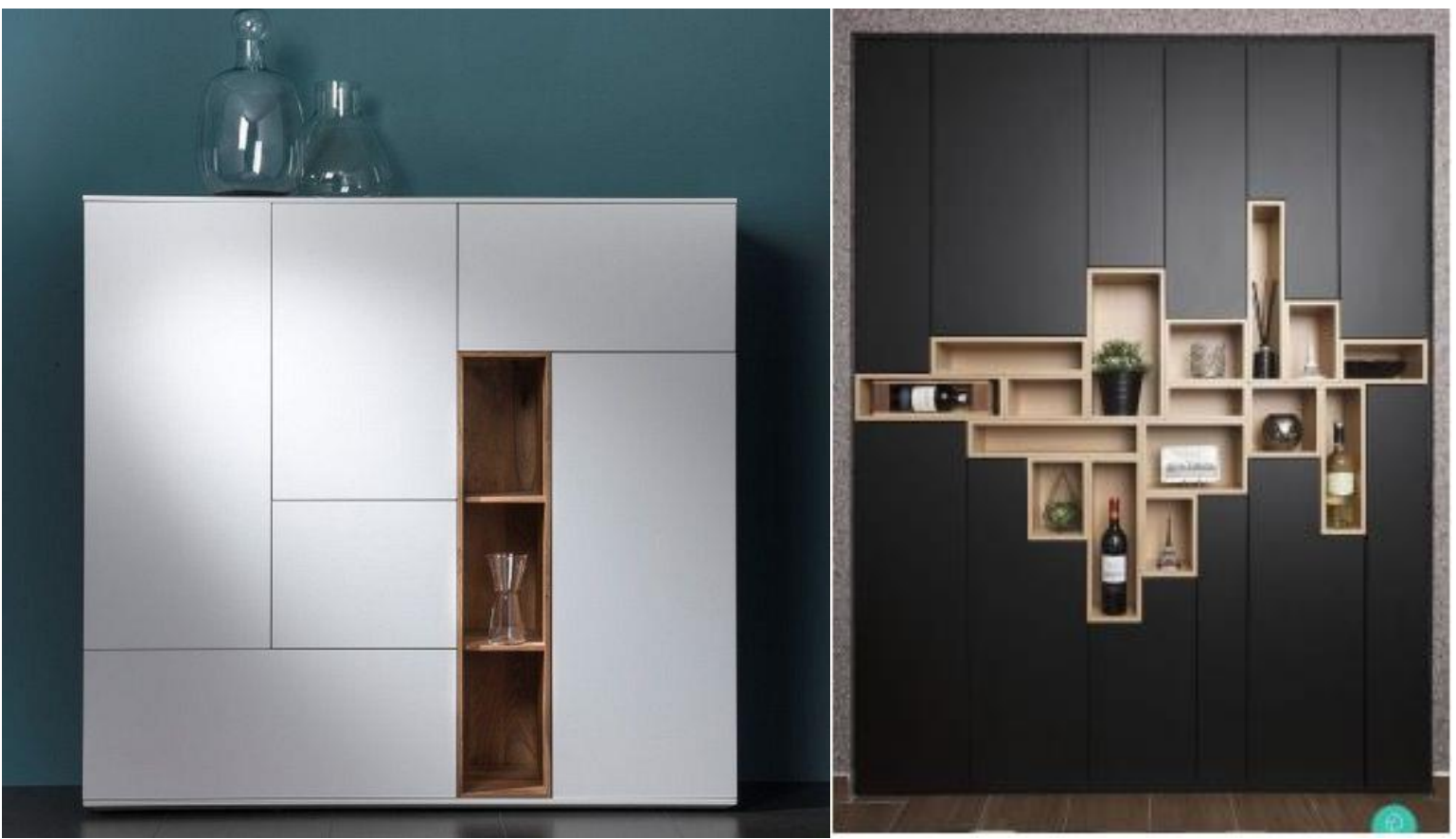

Şekil 5. Dolu ve boş alanların özel biçimlerle birbirine bağlandığı mobilyalar (Özel, 2021; URL-8)

\subsection{Orantı}

İki ya da daha fazla sayıda görsel biraraya geldiğinde orantı kavramı ortaya çıkmaktadır. Tasarımcı bakış açısıyla orantı boyutların birbiri ile ilişkisidir. Tasarım yüzeyleri arasında daima orantıya dayalı ilişki bulunmaktadır. Bir görsel unsurun diğer unsurlarla kurduğu orantısal ilişkiler tasarımda algıyı doğrudan etkilemektedir (URL-9) . Mobilyanın çeşitli parçalarının birbiri ile ölçü bakımından orantılı olması gerekmektedir. Orantısız tasarımlar genellikle insanda dayanımının yetersiz olduğu vb. hisler oluşturabilmektedir (Sofuoglu, 2013).

Mobilyada yüzeylerin bölümlenmesinin göze hoş gelen oranlarda olması çok önemlidir. Mobilyanın bütününü oluşturan elemanların her birinin birbiriyle ve bütünle oluşturacağ 1 ahenk için gözetilmesi gereken psikolojik kuralların etkisi, kapı şekillerinde verilmiştir (Şekil 6).

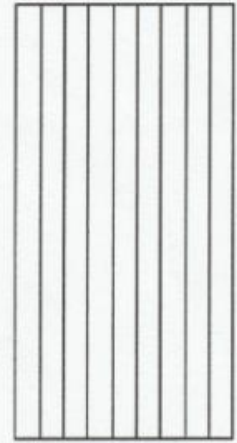

a)

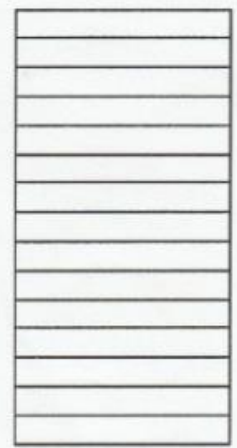

b)

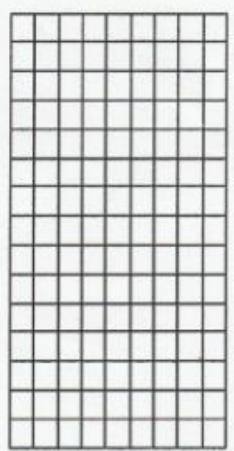

c)

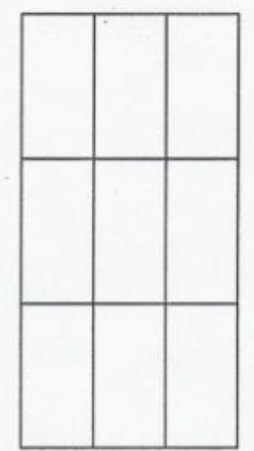

d)

Şekil 6. Değişik kapı bölümlemelerinin psikolojik etkileri (URL-10)

a)Kapı dar ve uzun bir görüntü vermektedir (düşey bölümlü), b) Düşey bölümlü kapıdan daha geniş gözükmektedir (Yatay bölümlü), c) Kapı küçük ve sıkıntılı görülmektedir (Küçük bölümlü), d)Kapı büyük ve rahat görünümlü (İri bölümlü) 
İnsan ölçeği, bir şeyin verdiği büyüklük hissidir. Bir iç mekanın veya içindeki öğelerin boyutları kişiye kendini küçük hissettiriyorsa, söz konusu mekanın insan ölçeğine sahip olmadığ düşünülmektedir. Mekan kişiyi küçültmüyor, mekan öğeleri, uzanma, mekan içi ferahlık veya hareket gibi boyutsal ihtiyaçlara uygunluk sağlıyorsa, mekanın insan ölçeğine uygun olduğu sonucuna varılabilir. Sürekli kullanılan ve bir arada olduğumuz için boyutlarına alışık olduğumuz öğeler, insan ölçeğini ortaya çıkaran öğelerdir. Kapılar, merdivenler, masalar, sandalyeler, koltuklar, tezgahlar buna örnek olarak verilebilir (Sofuoglu, 2013).

\section{6 Ölçü ve boyut}

Bir tasarım değişik ölçü ve belirli ölçülerdeki görsellerin birlikteliği ile meydana gelmektedir. Ölçüler büyüdükçe etkileyicilik ve algılayıcılık artar. Ölçü genel anlamıyla görsel ölçü ve insani ölçü olmak üzere ikiye ayrılmaktadır. Bir nesnenin boyutu her zaman göreceli olup, boyut hakkındaki yargımızı onu çevreleyen cisimler hakkındaki bilgilerimiz etkilemektedir. Genel olarak etrafta kıyaslıyabileceğimiz bir obje olmadığında nesnelerin boyutları hakkında fikir yürütmek oldukça zor olmaktadır. Bir resimdeki kutu şeklindeki cisim farklı insanlarda farklı etkiler bırakabilmektedir. Cismin boyutu hakkında kesin bir bilgisi olmayan insanlara aynı cismin kibrit kutusu, masa, çöp kutusu veya bir bina izlenimi verebilmektedir. Bu tip objeler hakkında geçerli bir fikir sahibi olabilmek için tasarım üzerinde daha önceden boyutu bilinen sembol veya başka bir obje gibi kıyaslayıcı unsurlar bulundurmak gereklidir. Şekil 7'de verilen örnek te mobilyanın üzerindeki televizyon, mobilyayı ölçü olarak algılamamıza yardımcı olur (Sofuoglu, 2013; Uğur, 2021).

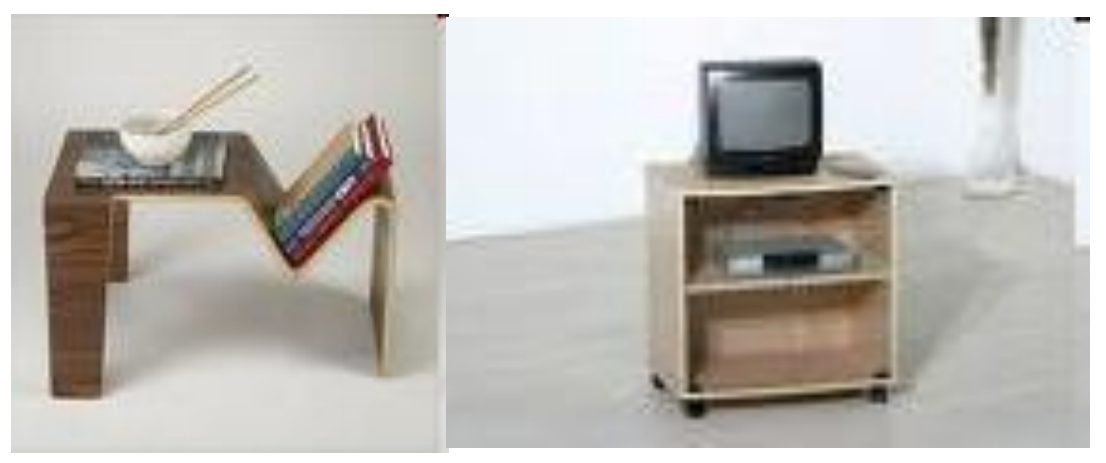

Şekil 7. Mobilyayı algılamayı etkileyen unsurlar (Sofuoglu, 2013).

Mobilya tasarım elemanı olarak ölçek ile mobilyanın insan ve mobilya elemanlarının kendi arasındaki ölçü ilişkisi anlaşılır. Mobilyalar onları kullanan insanlar ile orantılı olacak şekilde tasarlanmalı ve üretilmelidirler. Mobilya çevresinin ölçülerine de uymalı ve kendi içinde de belirli ölçülerde olmalıdır. (Kurtoğlu, 2005).

\subsection{Biçim ve form}

Biçimler, dikdörtgen, üçgen, geometrik ve serbest şekilli olmak üzere çok çeşitli şekillerdedir. Form ve fonksiyon arasında sıkı bir ilişki vardır. Tasarımın kullanışlı olmasının yanında, estetik açıdan da belirli bir seviyede olması gerekli ve tercih edilebilir olmalıdır (Kurtoğlu, Evci 1988).

Biçim ve şekil bir tasarımda rol oynayan en önemli öğelerdendir. Bir eşyanın genişliğini, yüksekliğini, derinliğini yani hacmini belirleyen dış çizgilere biçim denir. Doğadaki katı cisimler ifade edilebilen bir biçime ve forma sahiptirler. Formlar doğal ve yapay formlar olmak üzere iki bölümde incelenebilir. Ayrıca kurallı ve kuralsız olarak ikiye ayrılabilir (Bozkurt, 2021). Mobilya tasarımları dikdörtgen prizması, küp veya silindir şeklindedir. Tasarımcının bu tip geometrik formları göze çok batmayacak biçimde biçimlendirmesi gereklidir. Aksi durumda ortaya çıkan 
modeller arasında gözle görülür benzerlikler oluşur. Kuralsız formlar matematiksel olarak ifade edilemeyen geometrik şekillere benzemeyen, doğal olarak bulunan formlardır. Dağlar, ağaçlar, çeşitli bitkiler gibi kuralsız formlar mobilya tasarımlarında ve süslemelerinde sıklıkla kullanılmaktadır. Klasik mobilyalarda yaprak, insan vücudu, hayvan pençeleri gibi objeler mobilya süslemelerinde yer almıştır (Kurtoğlu, 1996).

Form bir tasarım kriteri olarak ürünlerin biçimlenmesi ve biçimleri ile ilişkili olarak biçime referans olan bir özellik olarak ele alınmaktadır. Form herkes tarafından görülen, hissedilen üç boyutlu değişmez, dışsal bir gerçeklik olarak, biçim ise bireyin algısı ile ilgili olan bireye göre değişen anlık bir gerçeklik olarak tanımlanabilir (Tütüncü, 2011).

Biçimler; beşgen, dikdörtgen geometrik ve serbest şekilli olmak üzere çok çeşitli şekillerde karşımıza çıkarlar. Form ve fonksiyon arasında sıkı bir ilişki bulunmaktadır. Kullanışlı1ık (fonksiyon) tek hedef değildir. Kullanışlılık kadar, güzellik (estetikle) ile ilgili gereksinimlerimizin de karşılanması gereklidir (Kurtoğlu, 2005)

\subsection{Renk}

Renk, ışığın değişik dalgaboylarının göze ulaşmasıyla meydana gelen algılamadır. Algılama, ışı̆̆ın nesneler üzerine çarparak ve kısmen soğurulup kısmen yansımasıyla çeşitlilik göstermektedir. Bu yansıma ve soğurulmalar neticesinde renk tonları veya renkler oluşmaktadır. Tüm dalga boyları göze ulaşırsa beyaz, hiç ulaşmaz ise siyah renk oluşur (URL-11). Renk içeren tasarımlarda, denge oluşturmak için, karşıt renkler kullanmak faydalı olmaktadır (URL-12). Tamamlayıcı renk armonisi Şekil 8'de verilmektedir.

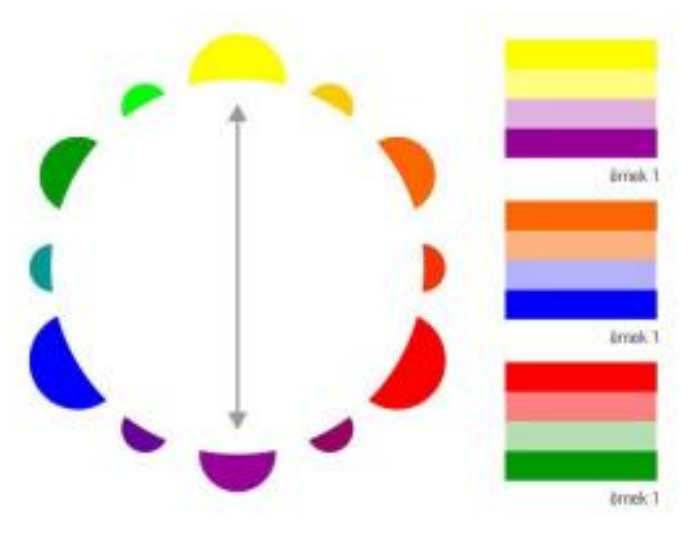

Şekil 8. Tamamlayıcı renk armonisi (URL-11)

Renk 3 elemanla ifade edilir. İsim: Bir rengin ismidir (Yeşil, sarı vb.), Değer: Rengin açıklık ve koyuluğunu ifade eder, Yoğunluk: Bir rengin saflık, şiddet veya doymuşluk derecesini gösterir (Kurtoğlu, Evci, 1988)

İnsanların yaşamları boyunca geçirdikleri farklı olaylar ve bu olaylardan etkilenmeleri söz konusudur. Yaşanılanların farklı renklerden hoşlanmalarına etkisi bulunmaktadır. Çocukların ve ilkel toplulukların canlı, kontras renklerden hoşlandığı görülürken, olgun ve bilgi düzeyi yüksek toplum ve bireylerin karışımın getirdiği daha doygun renkleri tercih ettikleri bir gerçektir. Toplumların yaşadıkları olaylar karşısında renk seçimlerini farklılaştırdıkları, savaş zamanı haki rengin seçiliyor olması da gözlemler arasında yer alır (Balcı ve Say 1981). Renkler ve psikolojik etkileri kısaca incelendiğinde (Sofuoglu 2013);

Sarı: En parlak renktir. Dikkat çekicidir. Uyarı 1şıklarında sarı renk kullanılmaktadır. Geçiciliğin, hüzün ve özlemin rengidir. Sarı renk bulunduğu ortamlarda insanda sevinç, coşku, 
üretkenlik ve verimlilik artışı sağlar, enerji verir. Sarı rengi seven insanlar yönetmeyi severler. Zıtt etkilere sahip olduğundan ve duygu ve zihin karışıklığına neden olabilir. Çalışma yapılan mekanlarda kullanılması uygun görülmez. İştah açar, sindirim sistemine olumlu etkisi bulunmaktadır. Kullanıldığı yüzeyi olduğundan daha yakın hissettirir. Işı̆̆ı az, geniş ve karanlık ortamlarda kullanıldığında aydınlık etkisi vermektedir (URL-13, URL-14)

Kırmızı: En uzun dalga boyuna sahiptir. Koyu bir arka fonla birlikte kullanıldığında görüntünün tamamında etkisini gösterebilmektedir. Canlılık ve dinamizmle ilgilidir. Mutluluğu ifade eder. Ataklığı, canlılığ 1 ve azim ve kararlılığ1 gösterir. Güç etkisi vardır. İştahı olumlu yönde etkiler (URL-14). Duygusallığı yükseltir, insanları daha hızlı karar almaya iter, kendini kontrol edemeyen insanlara negatif etki gösterir. Yüksek derecede dikkat çeker, logolarında ve paketlerin üzerinde sıklıkla tercih edilir. Uyarıcı ve tehlike belirten işaretlemelerde kullanılır. İyi ışık alan ve hareket yoğunluğu olan mekanlarda enerji, hareket ve dikkatin önemli olduğu mekanlarda, özellikle çocuk yoğunluğunun olduğu durumlarda kullanılabilir. Loş mekanlarda sıkıcı bir atmosfere neden olabilir (URL- 8).

Mavi: Denizler ve gökyüzü olarak dünyada hakim renklerdendir. Dinlendiriciliği ve edilgenliği anlatır. Koyu tonlarda ya da yoğun olarak kullanıldı̆̆ında moral bozan, kasvet veren etki açık tonlarda ya da beyazla karışık kullanıldığında, yatıştırıcı ve güven veren bir etki yaratır. Huzuru temsil eder ve sakinleştirir. Mavinin kan akışını yavaşlattığına inanılır. Batı kültürlerinde intiharları azaltmada etkisi olduğu için bu tip bina ve yapılarda (köprü ayakları gibi) maviye boyanmaktadır. Duvarları mavi renk ile boyanmış okullarda çocukların daha az yaramazlık yaptığı tespit edilmiştir (URL-14).

Yeşil: Doğanın ve baharın rengidir. Serinletici ve sakinleştirici bir etkiye sahiptir. Güven verir. O yüzden bankaların logolarında hakim renktir. Hastanelerde rahatlatıcı özelliğe sahip olduğundan dolayı tercih edilmektedir. Serbest geçiş simgesidir. Serinletici ve sakinleştirici bir etkiye sahiptir. Yeşil kendine saygı, adalet ve güveni temsil edebilirken, abartılması megaloman, otoriter ama küstah, alaycı bir ifade yayabilir (URL-14).

Pembe: Kırmızı gibi canlılık verir ama daha hafiftir. Neşe ve mutluluğum aynı zamanda hayallerin ve aşkın rengidir. Rahatlatıcı ve sakinleştirici özelliğe sahiptir. Hapishane, hastane odaları ve uyuşturucu merkezlerinin duvarlarında kullanılır (URL-14).

Kahverengi: Tutucu, emin ve besleyici bir renktir. Toprağın ve ahşabın rengidir. Ciddiyet, dayanıklılık, olgunluk, dostluk ve sadeliğin göstergesidir. Zihinsel konsantrasyonu sağlar. Ruhsal dinginlik, istikrar ve kararlılık kazandırır. Açık tonları çalışma odalarında, salon ve oturma odalarında krem-bej tonları ile birlikte kullanılabilirler. Zeminlerde kullanımı toprağı anımsatır. (URL-13).

Mor: Geleneksel olarak asaletle ilişkilendirilir. Yakınlık ve güzelliğe de işaret eder. Eskiden beri ihtişam ve lüksün olduğu ortamlarda kullanılmaktadır. İnsanların bilinçaltını korkuttuğu saptanmıştır. İntihar edenlerin beğendiği renktir. Derinlik ve değerliliği de sembolize eder (URL14).

Koyu renkler alanları olduğundan daha küçük gösterirken açı renklar alanları olduğundan daha büyük göstermektedir. Kırmızı, sarı ve turuncu vb. renkler mekana sıcaklık katarken, mavi ve yeşil de serinletir (URL-15). Uzmanlar renk seçimlerinin mekanın boyutu, bulunduğu yön ve aldığ 1 1şık miktarına göre seçilmesi gerektiğini önermektedirler.

Koyu sarı, turuncu, kırmızı ve kahverengi renklerin kullanıldığı ortamlar daha samimi bir ortamın meydana gelmesine sebep olabilir. Sarı ve turuncu renkler insanlara sıcak gelmektedir. Bu tip mekanlarda insanlar kendilerini daha huzurlu hissetmektedirler. 
Açık toprak renkleri insanı sakinleştirmekte, huzur vermekte, siyah renk soğuk ve itici bir etkiye sahip olmaktadır. Renklerin çeşitli mekanlarda çeşitli bakış açılarına göre kullanımlarına örnekler Şekil 9, 10 ve 11'de verilmektedir.
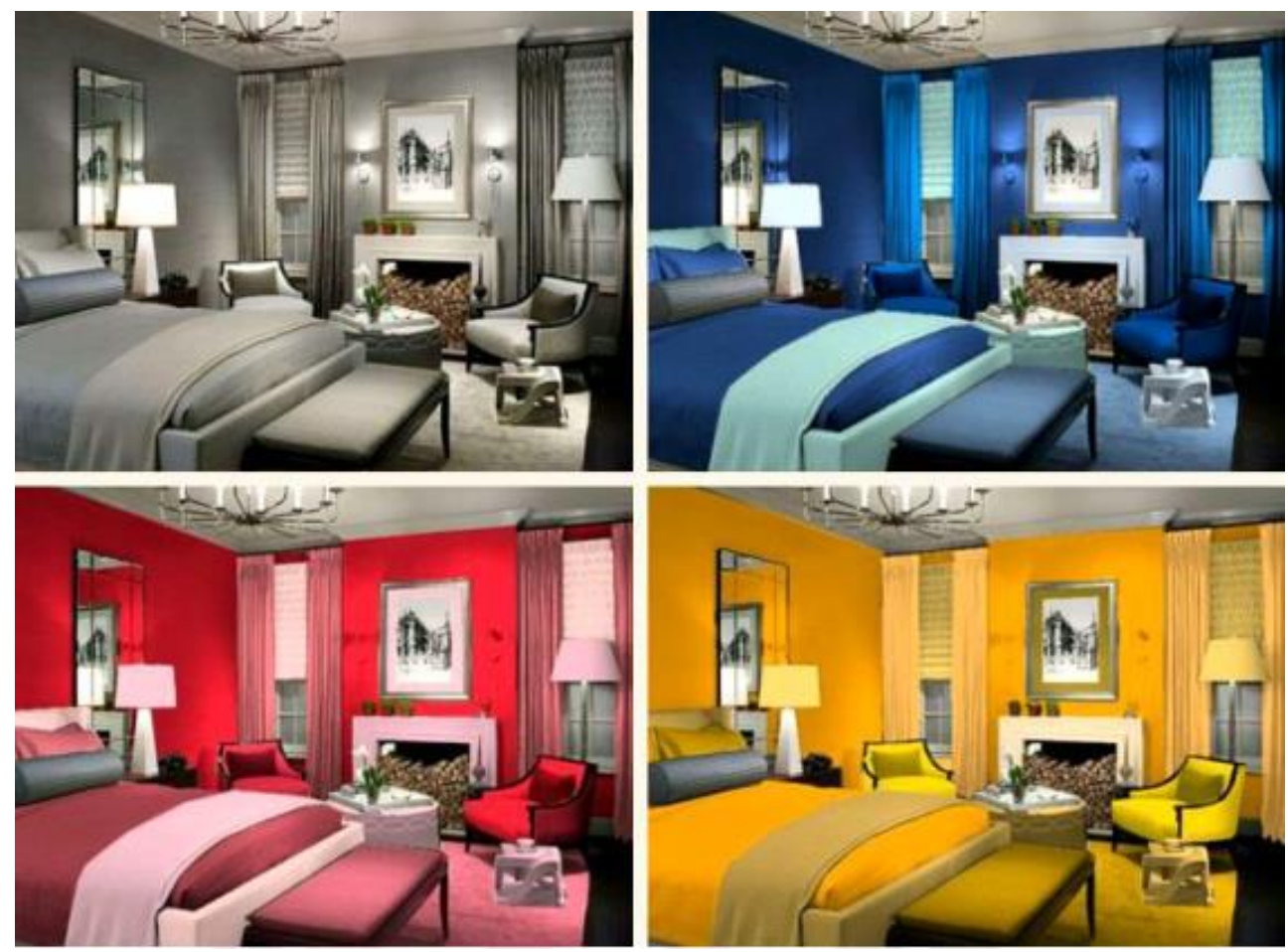

Şekil 9. Aynı mekanın farklı renkler kullanılarak görünümü (Uyan, 2019)

Çok parlak, fosforlu renkler insanları olumsuz etkileyebilmektedir. Her renk insanlarda farklı duygular uyandırmaktadır. Doğru seçim için titiz davranılmalıdır.

Çocuğun büyümesiyle birlikte renk tercihlerinde sıcak renkten, soğuk renge (kırmızı, sarı, turuncu gibi renklerden mavi, yeşil gibi renklere) doğru bir değişim gözlemlenmektedir (Konrot, 1989). 3 yaşından önceki dönemde renk seçiminde yoğunlaşma ve parlaklık etkili olmaktadır. Öte yandan renkler, çocukların psikolojik gelişiminde etkilidir. Örneğin; pembe rengin çocuk için huzuru, güveni ve anne sıcaklığını duyumsattığı yapılan çeşitli araştırmalarla ortaya çıkmıştır. Açık mavi gibi pastel tonlarda duvarları boyanmış odalarda çocuğun daha rahat ve çabuk uyuduğu gözlemlenmiştir (Tavşan, 1995). Sarı ve turuncu renk ise çocukta arkadaşlık duygusunu ve neşeyi pekiştirdiğinden dikkat çekici özelliği nedeniyle az ışık alan mekânlar ve bu mekânlarda yer alacak mobilyalarda kullanılması doğrudur. Pastel tonlarda yeşil renk, çocuk üzerinde dinginlik etkisi bırakması ve odayı geniş göstermesi nedeniyle kullanıma uygun bir renk olarak önerilmektedir.

Doğa ile özdeşleşmiş bir renk olan kahverenginin en fazla bulunduğu ahşap malzeme, mobilyalarda açık tonlarda olmak şartı ile ölçülü olarak kullanılmalıdır. Doğada az rastlanır bir renk olan morun ise, çocuk odası ve mobilyasında ölçülü olarak kullanılması gerekmektedir. Çünkü mor renk dalga boyu en uzun olan ve gözün görmekte zorlandığı, beyin tarafından en zor algılanan renk olduğu için bu rengin hâkim olduğu mekânda çocuğun fiziksel ve psikolojik açıdan olumsuz etkilenmesi söz konusudur. Kırmızı renk ise dalga boyu en kısa renk olduğundan en kolay ve çabuk algılanan renktir. Bu rengin çocuğun hareketlerinde hız artışına neden olması bir yana metabolizma hızı da artacağı için mekânda kullanımı ölçülü olmalıdır. 0-6 yaş grubu çocuk için oda tasarımında dikkat edilmesi gereken bir konu da dokudur. Çocuğun odanın ve mobilyaların biçim ile rengini doğru algılayabilmesi için tasarımda dokusal birlik sağlanmalıdır. Aynı renkte ancak farklı dokuya sahip iki yüzey, çocuk tarafından farklı renk ve tonlarda algılanabilmektedir. Çevresini görerek ve dokunarak algılayan çocuğa, 
doğru seçilmiş renk ve dokularla odasını ve eşyalarını sevdirebilmek mümkündür (Sandstrom, 1971;

Demirarslan, 2019)

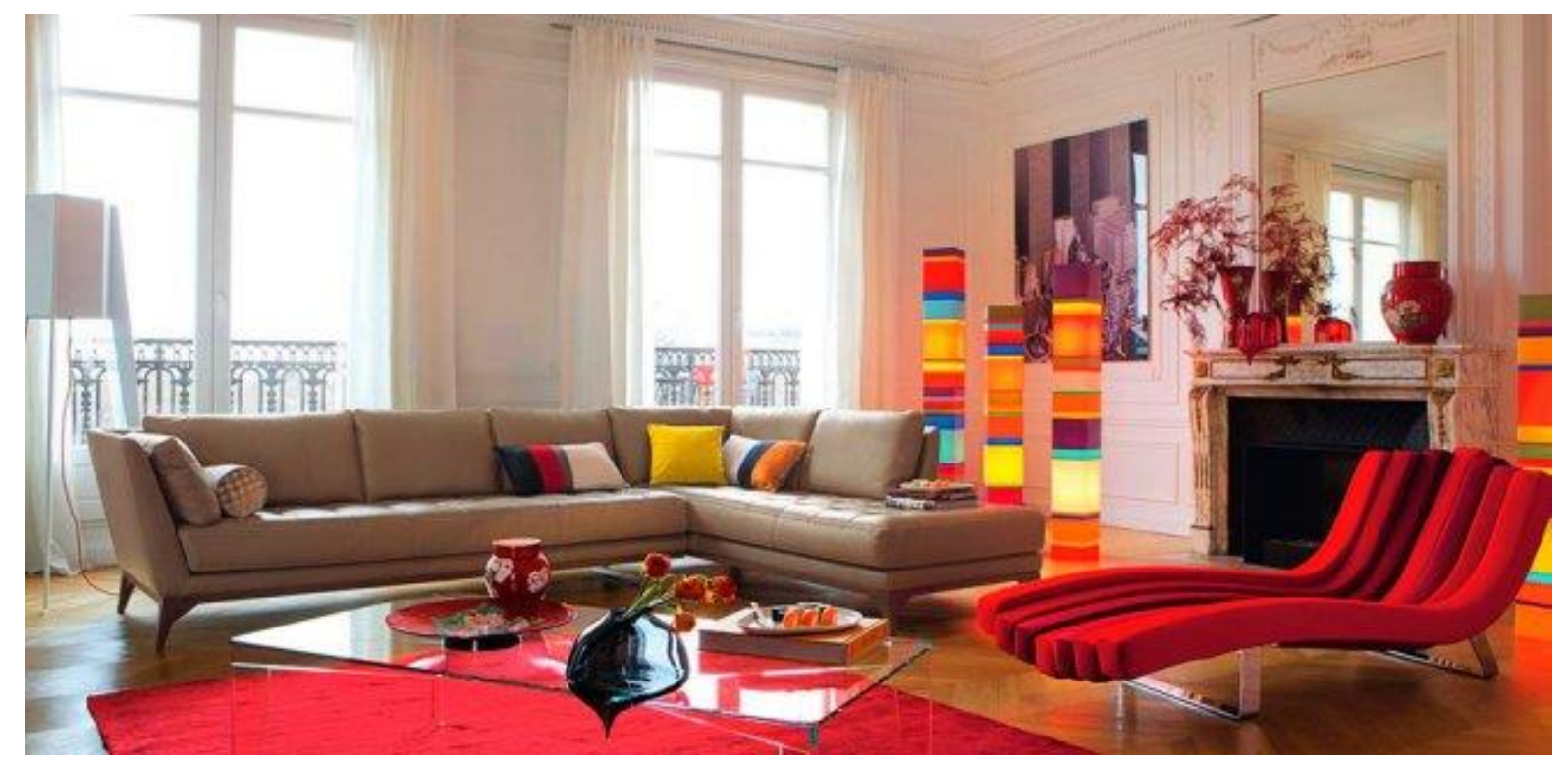

Şekil 10. Renklerin iç mekan ve mobilyalarda kullanımı (URL-16)

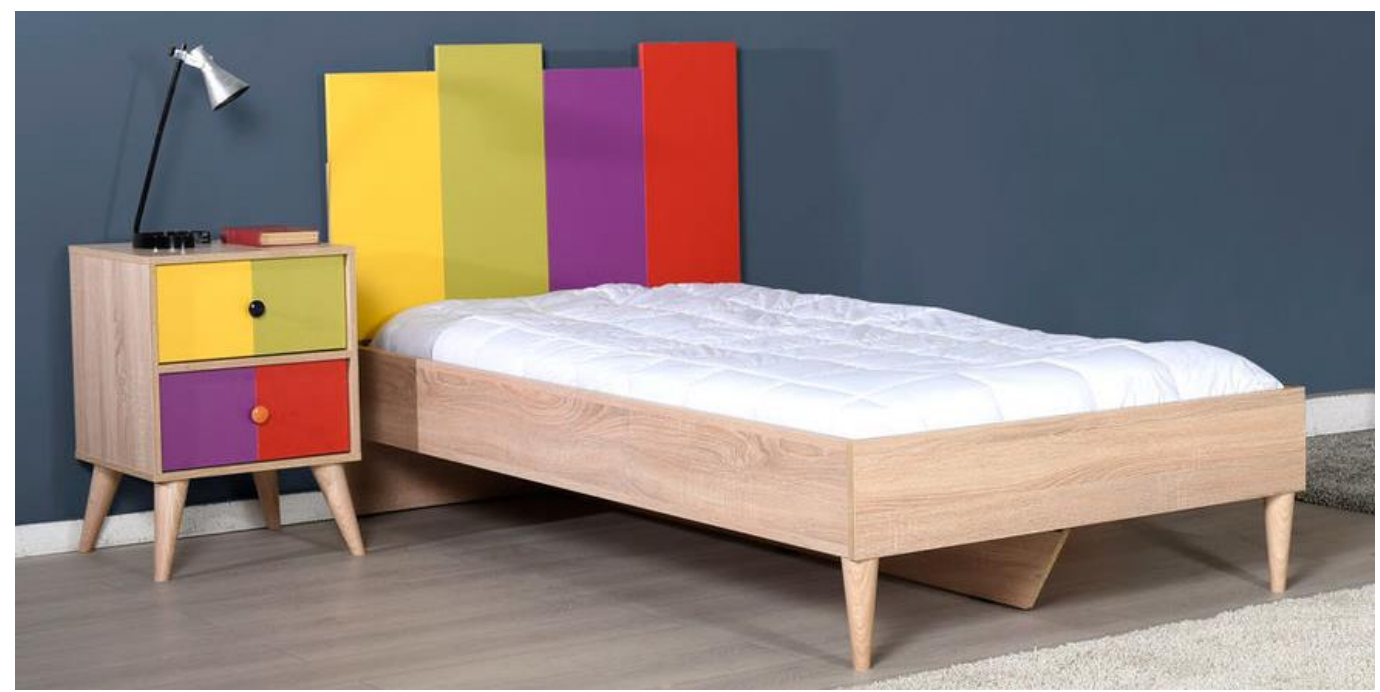

Şekil 11. Renklerin mobilyalarda belirgin etkisinin kullanımı (URL-17)

\subsection{Doku}

Mobilyanın tasarımını etkileyen önemli estetik kriterlerden birisi de kullanılan malzeme ve dokulardır. Tasarlanan ürünün, hedef kitleye ulaşabilmesi için bu kitlenin ekonomik, sosyal ve teknolojik beklentilerinin karşılanmasının yanında, ürünün ifade edilmesini sağlayan 'doğru' malzeme, doku ve renkle sunulması gereklidir (Usal, 2004). Mobilyada malzeme hem teknik hem ekonomik hem de estetik bir değer taşıması açısından oldukça önemlidir. Malzeme birçok noktada ürüne dair referans bilgileri içerir ve iletir. Ürünün tanıtımında da özellikle, kullanılan malzemelerin teknolojik özellikleri ve yenilikleri ifade edilebilmekte, bu yolla hedef kitle modern, çağdaş, üstün teknolojik özelliklere sahip vb. kavramlar ile özendirilmektedir. Malzemenin yapısı mobilyanın teknik özellikleri içinde ele alınsa da görsel ve dokunsal anlamda duyusal özellikler taşır. Malzemenin yapısal özelliği ve dokusu ayrı ayrı duyular olarak değil bütünsel bir yapıda algılanır. Algılama sürecinin sağlıklı yaşanması için bu 
özelliklerin birbirini dengelemesi beklenir (Tütüncü, 2011).

Ertaş’a (2007) göre doku, bir objenin karakteristiğini oluşturan özelliklerden birisidir. Tasarlanan ürünün kullanıcıyla olan ilişkisini etkiler. Yüzeyin sert veya yumuşak olması kullanıcıda daha farklı bir psikolojik etki meydana getirmektedir. Alexander'a (1977) göre doku dokunsal his meydana getirebilmesi için, yüzeyde girinti ve çıkıntıların olması gerekmektedir. Ayrıca görsel olarak dokunun etkisinin gösterebilmesi için, yüzeye 1şığın çarpması gerekmektedir. Farklı iki dokuya sahip aynı renkteki iki cisim farklı renklerde algılanabildiğinden dokunun renk hissini de değiştirdği sonucuna varlmaktadır (Ghorab, 2015).

Bir yüzeyin pürüzlü veya pürüzsüz olduğunu anlatmak için kullanılabilmektedir. Yüzeylerin karakterlerini oluşturan tasarım elemanı dokudur. Dokular genel olarak iki gruba ayrılabilir. Yapıları açısından doğal doku ve yapay doku olarak sınıflayabiliriz. Dokunun düzgün ve düzgün olmayan (kaba) yüzey etkileri bulunmaktadır (Kurtoğlu, 1996). Kaba yüzeyler, hareketli yüzeyler meydana getirerek form ve rengi saklayabilmektedir. Işı ve gölgeli yüzeyler oluştururlar. Düzgün yüzeyler ise form, renk ve mekana ait ilişkileri kuvvetlendirir. Soğuk, durgun ve sıkıcıdırlar (Doruk, 1973).

Renk, malzeme, doku, süs öğeleri gibi biçimi oluşturan elemanların moda faktörü yaratabilecek öğeler olabileceği gibi bir mobilya salt tasarımcısı veya ürünün biçimi ile de moda olabilmektedir (Vural, 2004)

Doku, içyapının dişa vurumudur. Doku insanın hem görme hem dokunma duyusuna yöneliktir. Doku tasarımında amaca uygun dokular oluşturabilmek için dokunun özelliklerinin çok iyi bilinmesi ve yararlanılması gerekir. Dokular oluşumları yönünden ikiye ayrılabilir. Her varlığın kendine özgü "doğal doku"su vardır (ağaç kabuğu, taş vb.). Doğa ürünü olmayan, insan eliyle üretilen nesnelerin dokuları "yapay doku” dur (kumaşlar, örgüler, deri vb.). Duyumları yönünden; gerçek dokular gözle görülen, aynı zamanda girinti çıkıntıları hissedilen dokulardır. Görsel doku ise tasarımda nokta, çizgi, açıklık, koyuluk ve renkle yapılan dokulardır. Hacim etkisi oluşturur. Yüzeydeki girinti ve çıkıntılar sadece gözle algılanır. Parmakla dokununca hissedilmez (Alpaslan Aker, 1981).

\section{SONUÇ VE ÖNERILER}

Mobilya tasarımı diğer mimari tasarımlar ve endüstrinin farklı alanlarındaki tasarımlardan farklı değildir. Böylelikle bu alanlarda kullanılan tasarım yöntemlerini mobilya tasarımları içinde kullanmak mümkündür. Tasarım sürecinde tasarım elemanları açısından önemli noktalar göz önüne alınarak tasarım gerçekleştirilmelidir.

Mobilya tasarımcıları tasarım süreçlerine yenilik getirerek; tek başına düzensiz görünen, tasarım elemanlarını oluşturan nokta, çizgi, yön ve doğrultu, yüzey, alan, orantı, ölçü ve boyut, biçim ve form, renk, doku'dan faydalanarak sonuçlandırmalıdırlar

Tasarım elemanlarının etkin kullanımı ve insan psikolojisi üzerindeki etkisinin bilinmesi ve bunun göz önüne alınarak tasarımın gerçekleştirilmesi tasarlanan mobilyanın istenen tasarım hedefine ulaşmasını sağlayacaktır.

Yatak odası için mavi, turkuaz, açık yeşil; banyo gibi ıslak mekanlarda beyaz, mavi, yeşil, turkuaz; mutfaklar da kırmızı, yeşil, sarı; oturma odaları, beyaz, mavi, açık ve doğal renkler; yemek odasında ve yemek yenen mekanlarda kırmızı, turuncu, yeşil ve sıcak renkler, küçük çocukların gittiği okullarda mavi, hastanelerde yeşil, pembe renk iç mekanlarda kulanılan ürünlerde ve yüzeylerde tercih edilebilir. Ayrıca dar mekanlarda açık renkler, geniş mekanlarda koyu renkler kullanım amacı da göz önüne alınarak kullanılması uygundur. 
İç mekânı kullanacak kişilerin yaşı, mekanın kullanım amacı ve beklenen fonksiyonuna uygun renklerin ve renk kombinasyonlarının (renk çemberindeki konumları, miktarları ve tür özellikleri konusunda birbiri ile uyumlu ilişkiler içerisinde olmalı, bütünlük sağlamalı) seçilmesi gerekmektedir. Böylelikle mekanı kullanacak kişilerin verimli hareket etmesine katkı sağlanacak ve insanların psikolojisi ve sağlı̆̆ üzerinde olumlu bir etki meydana getirecektir.

\section{KAYNAKLAR}

Alpaslan Aker, S. (1981). Tasarım mesleki resim, Ya-Pa Yayın pazarlama San ve Tic. A.Ş., Turan ofset, İstanbul.

Andarood, H.G. (2014). İ̧ mimarlık alanında görsel iletişim temelli grafik tasarım çözümlemeleri, Yayınlanmamış Yüksek lisans tezi, Hacettepe Üniversitesi Güzel Sanatlar Enstitüsü İç Mimarlık ve Çevre Tasarımı Ana Bilim Dalı, Ankara.

Aslan, F., Aslan, E., \& Atik, A. (2015). İç mekanda alg1. Inönü University Journal of Art and Design, 5 (11), 139-151

Balcı, Y.B., Say, N. (2003). Temel sanat eğitimi, Ya-Pa Yayın pazarlama San ve Tic. A.Ş., Kelebek matbaacılık, İstanbul.

Bozkurt, B. (2021) Temel Sanat Eğitimi ders sunumları, Ankara Üniversitesi, https://acikders.ankara.edu.tr/pluginfile.php/103049/mod_resource/content $/ 1 /$ Temel\%20Sanat\%20E\% C4\%9Fitimi\%20Hafta\%2010.pdf

Buyurgan, S., Buyurgan, U. (2012). Sanat ĕgitimi ve öğretimi. Pegem yayınları, Ankara, 130.

Ching, F. (2002). Mimarlık, biçim, mekân ve düzen, (Çev. Aydın, G.), Nobel yayınları. Ankara, 54.

Demirarslan, D. (2019). 0-6 yaş grubu çocuğun dünyasında mobilya tasarımı. Researcher Social Science Studies, 7 (2), 64-76.

Dinçer, A. (2011). Konutlarda mekân tasarımı kriterlerinin görsel algılama açısından incelenmesi, Yayınlanmamış Yüksek lisans tezi. Haliç Üniversitesi, Fen Bilimleri Enstitüsü, İstanbul.

Doruk, B. (1973). Mimari Tasarıma Giriş Programı Üzerine Bir Araştırma, İstanbul Teknik Üniversitesi, İstanbul

Ertaş, D.G. (2007). Yapısal özelliklerin endüstri ürünleri tasarımına etkileri. Yayınlanmamış doktora tezi, İstanbul Teknik Üniversitesi, Fen Bilimleri Enstitüsü, İstanbul.

Frieling, H., 1954, Mensch-Farbe-Raum, Munchen

Ghorab, P. (2015). Kent mobilyalarının temel tasarım ilkelerine göre değerlendirilmesi, Yayınlanmamış yüksek lisans tezi, İstanbul Aydın Üniversitesi Fen Bilimler Enstitüsü, İstanbul.

Gökaydın, N. (2010). Temel sanat eğitimi, Moss eğitim, Ankara, 72.

Kesen, N. (2005). Sanat sözlügü, Nobel yayınları. Ankara, 237.

Kesen, N. (2009). Sanat sözlüğü, Ütopya yayınları. Ankara, 79.

Konrot, M. (1989). Okul öncesi çocukların oyun odası duvarları için seçtikleri renkler, Yayınlanmamış yüksek lisans tezi, Anadolu Üniversitesi Eğitim Fakültesi, Eskişehir.

Kumas Şenol, N., Elmas, A.O. (2021). Deneysel kolaj uygulamalarının temel tasarım elemanları ile incelenmesi, Art-Sanat, 15, 183-201. https://doi.org/10.26650/artsanat.2021.15.0008

Kurtoğlu, A. (1996). Mobilya ve Ăgaç Konstrüksiyonlert dersi lisans ders notlar1 (Basılmamıştır), İstanbul Üviversitesi, Orman Fakültesi, Orman Endüstrsi Mühendisliği Bölümü, İstanbul

Kurtoğlu, A. (2005). Mobilya Endüstrisi dersi lisans ders notları (Basılmamıştır), İstanbul Üviversitesi, Orman Fakültesi, Orman Endüstrsi Mühendisliği Bölümü, İstanbul

Kurtoğlu, A., Evci, F., (1988). Mobilya tasarımı, İstanbul Üniversitesi Orman Fakültesi Dergisi, Seri B, 38 (4), 49-62.

Martel, C. (1995). Ben enerjiyim, Arion Yayınevi, İstanbul, 85.

Özel, Y. (2021). İç mekân kurgusunda mobilya ve mekân kompozisyonu ilişkisi. Avrupa Bilim 
ve Teknoloji Dergisi, (25), 94-104.

Özdemir, T. (2005) Tasarımda renk seçimini etkileyen kriterler, Ç.Ü. Sosyal Bilimler

Enstitüsü Dergisi, Cilt 14, Say1 2, 2005, s.391-402.

Özkartal, M. (2009). Resim sanatında çizgi ve çizgi ritmi üzerine. Sanat ve Tasarım Dergisi, 4 , $55-72$.

Sandstrom, C.J. (1971). Çocuk ve gençlik psikolojisi, (Çeviren: Refia Semin), İ̈̈ Edebiyat Fakültesi Matbaas1, Yay. No: 1614, İstanbul.

Sengir, S., Yücel, A. (2016). Temel tasarımda çizgi üzerine. ODÜ Sosyal Bilimler Araştırmaları Dergisi (ODÜSOBİAD), 6 (15), 478-487.

Sofuoglu, S. D. (2013). Estetik ve tasarım psikolojisi, Basılmamış Ders Notları, Dumlupınar Üniversitesi Simav Teknik Eğitim Fakültesi, Kütahya

Tavşan, F. (1995). Trabzon konutları üzerinde çocuk odaları mekân ve donatı özellikleri üzerine bir araştırma. TÜ FBE Yüksek Lisans Tezi, Trabzon.

Tütüncü, D. (2011). Mobilya tasarımını değerlendirmede kullanılan temel kriterlerin kullanıcı algısı açısından önceliklerinin belirlenmesi, Yayınlanmamış yüksek lisans tezi, Anadolu Üniversitesi Fen Bilimleri Enstitüsü, Endüstriyel Tasarım Anabilim Dalı, Eskişehir.

Uğur, E. (2021), Tipoğrafi II, Final Ders notları, İstanbul Üniversitesi. https://cdn.istanbul.edu.tr/FileHandler2.ashx?f=tipografi-ii-final-ders-notlari-2018.pdf

Uyan, S. (2019). Tekstilin iç mekân ve mobilya tasarımına etkileri, Yayınlanmamış Yüksek lisans tezi, Marmara Üniversitesi Güzel Sanatlar Enstitüsü İç Mimarlık Anasanat Dalı, İstanbul.

Vural, M. (2004). Doğadaki formların mobilya tasarımına etkisi, Yayınlanmamış yüksek lisans tezi, Mimar Sinan Üniversitesi Fen Bilimleri Enstitüsü, İstanbul.

Yılmaz, M. (2010). Görsel sanatlar eğitiminde uygulamalar. Data yayınları, Ankara, 29.

URL-1. https://tr.pinterest.com/pin/15410823708893003/ (Erişim Tarihi: 08.10.2021)

URL-2. http://www.fotografya.gen.tr/yazdir?9C18665ABC1A0A5F839F6C02000A26C2 (Erişim Tarihi: 08.10.2021)

URL-3. https://www.joom.com/tr/products/5ba3757f8b451301c6b7a5c4 (Erişim Tarihi: 08.10.2021)

URL-4. https://www.balkanraf.com/urun/helezon-aski/ (Erişim Tarihi: 08.10.2021)

URL-5. https://www.koctas.com.tr/akordiyon-aski/p/1000192709 (Erişim Tarihi: 08.10.2021)

URL-6. https://www.sivasgozdemobilya.com/urun/ekonomik-genis-5-cekmeceli-sifonyer85x45x95cm (Erişim Tarihi: 08.10.2021)

URL-7. https://www.minarmobilya.com/urun/kale-4-kapakli-2c-dolap-pera-ceviz (Erişim Tarihi: 08.10.2021)

URL-8. https://tr.pinterest.com/pin/448530444142843843/ (Erişim Tarihi: 08.10.2021)

URL9.

https://avys.omu.edu.tr/storage/app/public/abdulkerim.turkaya/132881/GTG_Sunu_6.pdf (Erişim Tarihi: 08.10.2021)

URL-10. https://ahsapteknolojisi.blogspot.com/2012/03/kapilar.html?view=timeslide(Erişim Tarihi: 8.10.2021)

URL-11.

http://web.hitit.edu.tr/dosyalar/duyurular/hulyacakmak@ hititedutr011220189A6L8V9X.pdf (Erişim Tarihi: 8.10.2021)

URL-12.

https://acikders.ankara.edu.tr/pluginfile.php/139879/mod_resource/content/1/1.\%20haftad\%C3\%B6n\%C3\%BC\%C5\%9Ft\%C3\%BCr\%C3\%BCld\%C3\%BC.pdf (Erişim Tarihi: 08.10.2021)

URL-13.https://www.evimitasarla.net/ev-dekorasyon-fikirleri-blog/mekanlardakullanilan-renklerin-insanlar-uzerindeki-etkileri/ (Erişim Tarihi: 08.10.2021) 
URL-14. https://tr.wikipedia.org/wiki/Renk (Erişim Tarihi: 08.10.2021)

URL-15. http://www.biyolojiegitim.yyu.edu.tr/ders/renk/renkcetveli.html (Erişim Tarihi: 08.10.2021)

URL-16. https://altinozmobilya.com/dekorasyonda-renk-uyumu/ (Erişim Tarihi: 08.10.2021)

URL-17.https://www.adoremobilya.com/adore-rainbow-genc-odasi-tek-kisilik-karyolakry-920-sx-2-sonoma- (Erişim Tarihi: 08.10.2021) 


\section{EXTENDED ABSTRACT}

Introduction: Furniture design is similar to architectural design and designs in many branches of industry. The design methods used in these branches can also be used in furniture design. The variety of results obtained in the design process depends on the designer. The effective use of basic design elements is an indispensable requirement for the design process. For this reason, product designers bring innovation to the design processes.

General Design Elements and Their Psychological Effects: They conclude the irregular pieces by using the point, line, direction, surface, area, proportion, size and dimension, form and form, color and texture that constitute the design elements. Knowing the effective use of design elements and their effects on human psychology will enable the designed furniture to reach the desired design goal. After giving basic information about design elements, the study explains its effect on human psychology.

Although the point is conceptually formless and shapeless, its presence begins to feel when it enters the field of view. The line consists of infinite points and is essential in design. The line allows our imagination to be expressed. You can add movement, vitality, interest, etc., to a design using different aspects. Psychological effects can be gained. When the same lines are used horizontally or vertically in designs, they leave different effects. It consists of infinite points and is essential in design. Surfaces express different psychological effects according to the positions of their dimensions. Area; It affects our visual perception in two ways, closed and open. Cabinet covers and drawers provide filled areas in furniture, and empty areas are provided by shelf spaces and spaces in the furniture body. Proportion arises when two or more images come together. As the dimensions increase, the impressiveness and perceptiveness increase. Measurement is generally divided into two as visual measurement and human measurement. The shapes come in a wide variety of shapes, including rectangular, triangular, geometric, and free-form. There is a close relationship between form and function. In addition to being functional, the design should also be at a certain level in terms of aesthetics. When colors and their psychological effects are considered in essence; Yellow: Is the brightest color. It is remarkable. Yellow, the brightest color of the spectrum, is commonly used in images depicting fresh ideas, creative projects, or new business initiatives. studies have scientifically proved yellow to enhance mental activity and heighten awareness and energy levels. Red is vitality and dynamism. It shows aggression, vitality and perseverance and determination. As a primary color, red is a color entirely its own - that is to say, no other colors can come together to form a perfect red. In RGB, red is comprised of $100 \%$ red, $0 \%$ green, and $0 \%$ blue. Associated with energy, war, danger, strength, power, determination, passion, desire, and love. Enhances human metabolism, increases respiration rate, and raises blood pressure. It attracts attention more than any other color, at times signifying danger. Red is vitality and dynamism. It shows aggression, vitality and perseverance and determination. Blue: denotes relaxation. Green is the color of nature and spring. It has a cooling and calming effect. It gives confidence. Pink has relaxing and calming properties. Though it has a great number of shades and undertones, pink is most commonly known to be a pale red mixed with white. This colour represents a gentle type of love Pink stands for tenderness, vulnerability, and youth It is a calming, non-threatening color. It is linked to innocence, hope, and optimism. Pink can be linked to childhood sweetness and innocence, sometimes appearing as naïve or silly. A beautiful mixture of red and purple. Purple is often associated with luxury and power. It symbolizes power, nobility, luxury, and ambition. White is the universal symbolic color for purity, wholeness, and innocence. It makes us think of new beginnings, perfection, and elegance and serenity. The bridal dress and the doctor's uniforms are also white because they represent purity, order, and offer comfort and hope. Black is highly versatile and, depending on which angle you approach it from, you can see it as elegant, mysterious, or downright depressing — associated with power, elegance, formality, death, evil, and mystery. A mysterious color associated with fear and the unknown. Denotes strength and authority; it is considered a very formal, elegant, and prestigious color. The symbol of grief. Red, yellow and orange etc. At the same time, colors add warmth to the space, blue and green cool. Experts suggest that color choices should be chosen according to the size of the space, the direction and the amount of light. Each color affects people differently. Care must be taken to make the right choice. Colors are effective in the psychological development of children. The texture is one of the properties that make up the characteristic of an object. Every having its own "natural texture" (bark, stone, etc.). The textures of non-natural, man-made objects are "artificial textures" (fabrics, knits, leather, etc.).

Conclusion and Suggestions: Furniture designing people and institutions will be able to use design elements from a commercial point of view optimally. Human psychology is important, and the desire to like and buy the product should be created. Especially in common areas (school, hospital, hotel, conference hall, lobby, etc.), the desired psychological effect (peace, movement, confidence, etc.) can be created when the furniture in which the designs are made is used, considering these factors. Dark colors show areas smaller than they are, while light colors show larger. As a result, with the appropriate and conscious use of each design parameter, the effect of the designed product on the users can be as desired. 